\title{
ANALISIS KINERJA KEUANGAN PEMERINTAH DAERAH DALAM PENGELOLAAN ANGGARAN PENDAPATAN DAN BELANJA DAERAH DI KABUPATEN ACEH TIMUR
}

\author{
Krisniawati $^{1}$, Muhammad Zulkarnain ${ }^{2}$, Yuliana ${ }^{3}$
}

\begin{abstract}
Regional financial performance is one measure that can be used to see the ability of a region to carry out regional autonomy, which can be seen from the level of independence, effectiveness and efficiency. This research was conducted with the aim of analyzing the financial performance of local governments in managing regional revenue and expenditure budgets in East Aceh District. This study uses secondary data sourced from the report on the realization of the East Aceh Regency budget from 2010 to 2018. Data were analyzed using the ratio of regional independence, level of effectiveness and efficiency. The results showed that the Regional Original Revenue in East Aceh Regency for the budget was still large compared to the realization, then for subsidies in the central, provincial and loan governments experienced development every year as well as regional spending, which increased every year according to regional development needs. Meanwhile, the financial performance of the regional government of East Aceh Regency based on the calculation of the ratio is included in the criteria not yet independent, ineffective but efficient.
\end{abstract}

Keywords: Financial Performance, Independence, Effectiveness, Efficiency.

\footnotetext{
${ }^{1}$ Sekolah Tinggi Ilmu Manajemen Pase Langsa, krisniawati2892@gmail.com

${ }^{2}$ Sekolah Tinggi Ilmu Manajemen Pase Langsa, m.zulkarnain28@gmail.com

3 Sekolah Tinggi Ilmu Manajemen Pase Langsa, yulieana2581@gmail.com
} 


\section{PENDAHULUAN}

Perwujudan dari transparasi dan akuntabilitas keuangan negara diwujudkan melalui penyusunan laporan keuangan. Tujuan pelaporan pemerintah daerah untuk menyajikan informasi yang berguna dalam pengambilan keputusan dan pertanggungjawaban pemerintah daerah. Sebagai pihak yang bertugas dan mengelola sumber daya yang dipercayakan dalam menjalankan aktifitas pemerintahan, pembangunan dan pelayanan masyarakat, Pemerintah daerah wajib menyampaikan laporan pertanggungjawaban keuangan daerahnya untuk dinilai apakah berhasil menjalankan tugasnya dengan baik atau tidak. Pengelolaan keuangan daerah menjadi penting dalam strategi pemberdayaan pemerintah daerah untuk pelaksanaan otonomi daerah dan mewujudkan desentralisasi yang luas, nyata dan bertanggung jawab.

Kinerja keuangan merupakan suatu kegiatan untuk melakukan pelaporan keuangan menurut standar keuangan yang telah ditetapkan. Indikator kinerja keuangan adalah ukuran kualitatif dan kuantitatif yang menggambarkan tingkat pencapaian suatu sasaran atau tujuan yang telah ditetapkan dengan memperhitungkan indikator masukan (input), keluaran (output), hasil, manfaat dan dampak. Ruang lingkup keuangan daerah terdiri dari keuangan daerah yang dikelola langsung dan kekayaan daerah yang dipisahkan.

Menilai kinerja keuangan pemerintah daerah dapat dilakukan dengan cara melihat kinerjanya melalui Laporan Realisasi Anggaran. Laporan realisasi anggaran menggambarkan perbandingan antara anggaran dengan realisasinya dalam suatu periode pelaporan. Laporan realisasi anggaran juga menyediakan informasi yang berguna dalam memprediksi sumber daya ekonomi yang akan diterima untuk mendanai kegiatan pemerintah daerah dalam periode mendatang dengan cara menyajikan laporan secara komparatif. Secara umum kinerja keuangan pemerintah daerah menggunakan analisis rasio keuangan yang terdiri dari rasio kemandirian keuangan daerah yang menggambarkan mengenai Pendapatan Asli Daerah dibandingkan dengan total penerimaan daerah (Dana Alokasi Umum, Dana Alokasi Khusus, Bagi Hasil Pajak, pinjaman daerah dan dana Otsus bila ada).

Kabupaten Aceh Timur merupakan salah satu daerah yang terletak di Provinsi Aceh dan telah melaksanakan otonomi daerah dan memanfaatkan sejumlah sumber daya yang dimiliki oleh daerahnya. Namun, Kabupaten Aceh Timur masih sangat bergantung pada pemerintah pusat hal ini terlihat dari masih sangat besarnya subsidi dana perimbangan daripada pendapatan asli daerahnya. Pemerintah harus melakukan usahausaha dalam pengelolaan dan menggali sumber-sumber pendapatan yang ada yang akan digunakan untuk belanja. Pendapatan asli daerah Kabupaten Aceh Timur pada tahun 2015 sebesar Rp 94.072.964.671 dan di tahun 2016 mengalami penurunan menjadi sebesar Rp 43.605.152.800. Terjadinya penurunan Pendapatan Asli Daerah di Kabupaten Aceh Timur di tahun 2016 dikarenakan di tahun sebelum realiasi belum mencapai 100\% sehingga tahun 2016 anggaran Pendapatan Asli Daerah diturunkan. 
Sementara realisasinya di tahun 2015 sebesar Rp 99.704.908.472 dan ditahun 2016 sebesar Rp 36.398.156.147.Penurunan realisasi Pendaptan Asli Daerah di tahun 2016 dikarenakan di tahun 2016 terdapat penurunan sub pendapatan retribusi. Penurunan juga terjadi karena kurang maksimalnya dalam mengumpulkan retribusi daerah. Kemudian nilai belanja di Kabupaten Aceh Timur tahun 2015 sebesar Rp 1.445.866.215.355 dan tahun 2016 meningkat sebesar Rp 1.528.899.541.935. Peningkatan belanja daerah tersebut sesuai dengan kebutuhan daerah yang terus meningkat sehingga memerlukan belanja yang juga meningkat. Kecilnya jumlah Pendapatan Asli Daerah dibandingkan dengan belanja daerah, memberikan gambaran bahwa daerah ini belum bisa dikatakan mandiri. Hal tersebut juga karena Pendapatan Asli Daerah belum dapat memenuhi belanja daerahnya, sehingga Kabupaten Aceh Timur memerlukan bantuan pemerintah pusat dalam hal ini adalah penerimaan transfer pusat.

Penelitian ini dilakukan untuk mengetahui kinerja keuangan pemerintah daerah dalam pengelolaan anggaran pendapatan dan belanja daerah di Kabupaten Aceh Timur pada tahun 2010 sampai dengan tahun 2018 berdasarkan rasio kemandirian, tingkat efektivitas dan efisiensi.

\section{Kinerja Keuangan Pemerintah Daerah}

Kinerja keuangan pada pemerintah daerah adalah keluaran atau hasil dari kegiatan atau program yang akan atau telah dicapai sehubungan dengan penggunaan anggaran daerah dengan kualitas dan kuantitas yang terukur, kemampuan daerah dapat diukur dengan menilai efisien atas pelayanan yang diberikan kepada masyarakat (Sumarjo dalam Nurulafifah ,2012:3). Halim (2012:78) menyatakan bahwa, kinerja keuangan daerah atau kemampuan daerah merupakan salah satu ukuran yang dapat digunakan untuk melihat kemampuan daerah dalam menjalankan otonomi daerah.

Dengan demikian maka dapat diketahui bahwa kinerja keuangan pada setiap pemerintah daerah baik di tingkat provinsi, kabupaten maupun kota merupakan gambaran kondisi hasil dari kegiatan atau program yang akan atau telah dicapai sehubungan dengan penggunaan anggaran daerah dengan kualitas dan kuantitas yang terukur, kemampuan daerah dapat diukur dengan menilai efisien atas pelayanan yang diberikan kepada masyarakat.

Adapun pihak-pihak yang berkepentingan dengan rasio keuangan pemerintah daerah (Halim,2012:98) adalah :

a. Pihak eksekutif sebagai landasan dalam menyusun APBD berikutnya.

b. Pemerintah pusat/provinsi sebagai masukan dalam membina pelaksanaan pengelolaan keuangan daerah.

c. Masyarakat dan kreditur, sebagai pihak yang akan turut memiliki saham pemerintah daerah, bersedia memberi pinjaman maupun membeli obligasi.

Tujuan pengukuran kinerja keuangan daerah (Halim, 2012:99), adalah sebagai berikut: 
IHTIYATH Jurnal Manajemen Keuangan Syariah

Vol. 5 No. 1, September 2021

a. Untuk menilai efisiensi dan efektivitas pengelolaan keuangan dan pendayagunaan aset yang dimiliki.

b. Untuk mengetahui kekuatan dan kelemahan kinerja keuangan suatu instansi serta mengevaluasi kinerja keuangan dan menetapkan tujuan untuk kinerja dimasa yang akan datang.

\section{Analisis Kinerja Keuangan Pemerintah Daerah}

Menurut Utama (2012:99), menganalisa keuangan daerah dapat menggunakan beberapa rasio, yaitu:

a. Rasio kemandirian

Rasio kemandirian keuangan daerah menunjukkan kemampuan pemerintah daerah dalam membiayai sendiri kegiatan pemerintahan, pembangunan dan pelayanan kepada masyarakat. Rasio kemandirian dihitung dengan membagi total PAD dengan total belanja daerah dalam satuan persen. Semakin tinggi rasio ini berarti tingkat ketergantungan daerah terhadap bantuan pihak pemerintah pusat dan provinsi semakin rendah, demikian pula sebaliknya.Rasio ini juga menggambarkan tingkat partisipasi masyarakat dalam pembangunan daerah.Semakin tinggi rasio ini berarti semakin tinggi partisipasi masyarakat dalam membayar pajak dan retribusi daerah yang merupakan komponen dari PAD. Secara sederhana rasio kemandirian dapat diformulasikan sebagai berikut:

$$
\text { Rasio Kemandirian }=\frac{\text { Pedapatan Asli Daerah }}{\text { Total Penerimaan }} \times 100
$$

Pola hubungan pemerintah pusat dan daerah serta tingkat kemandirian dan kemampuan keuangan daerah seperti berikut ini,Mahsun(2014:152).

1) Jika rasio antara 0-25\% maka kemampuan keuangan rendah sekali sedangkan pola hubungan instruktif, yaitu peranan pemerintah pusat lebih dominan daripada kemandirian pemerintah daerah.

2) Jika rasio > 25-50\% maka kemampuan keuangan daerah rendah dan pola hubungan konsultatif, yaitu campur tangan pemerintah pusat sudah mulai berkurang dan lebih banyak pada pemberian konsultasi.

3) Jika rasio > 50-75\% maka kemampuan keuangan daerah sedang dan pola hubungan partisipatif, yaitu pola di mana peranan pemerintah pusat semakin berkurang mengingat tingkat kemandirian daerah otonom bersangkutan mendekati mampu melaksanakan urusan otonomi.

4) Jika rasio > 75-100\% maka kemampuan keuangan daerah tinggi dan pola hubungan delegatif, yaitu campur tangan pemerintah pusat sudah tidak ada lagi karena daerah telah benar-benar mampu dan mandiri dalam melaksanakan urusan otonomi daerah 
b. Rasio efektivitas

Pengertian efektivitas berhubungan dengan derajat keberhasilan suatu operasi pada sektor publik sehingga suatu kegiatan dikatakan efektif jika kegiatan tersebut mempunyai pengaruh besar terhadap kemampuan menyediakan pelayanan masyarakat yang merupakan sasaran yang telah ditetapkan sebelumnya.Rasio efektivitas merupakan tingkat pencapaian pelaksanaan suatu kegiatan atau prestasi yang dicapai oleh pemerintah daerah yang diukur dengan membandingkan realisasi pendapatan dengan anggaran pendapatan, dalam satuan persen.

$$
\text { Rasio Efektivitas }=\frac{\text { Realisasi Pedapatan }}{\text { Anggaran Pendapatan }} \times 100
$$

Nilai efektivitas diperoleh dari perbandingan sebagaimana tersebut diatas, diukur dengan kriteria penilaian kinerja keuangan Mahsun(2014:153).

1) Jika diperoleh nilai kurang dari $100 \%(\mathrm{x}<100 \%)$ berarti efisien.

2) Jika diperoleh nilai sama dengan $100 \%(\mathrm{x}=100 \%)$ berarti efisien berimbang.

3) Jika diperoleh nilai lebih dari 100\% ( $x>100 \%)$ berarti tidak efisien.

c. Rasio efisiensi

Rasio efisiensi merupakan tingkat pencapaian pelaksanaan suatu kegiatan atau prestasi yang dicapai oleh pemerintah daerah yang diukur dengan membandingkan belanja operasi dengan realisasi penerimaan yang telah ditetapkan dalam satuan persen.Semakin kecil rasio ini, maka semakin efisien, begitu pula sebaliknya.Pada sektor pelayanan masyarakat adalah suatu kegiatan yang dilakukan dengan baik dan pengorbanan seminimal mungkin. Suatu kegiatan dikatakan telah dikerjakan secara efisien jika pelaksanaan pekerjaan tersebut telah mencapai hasil (output) dengan biaya (input) yang terendah atau dengan biaya minimal diperoleh hasil yang diinginkan. Rasio ini dihitung dengan:

$$
\text { Rasio Efisiensi }=\frac{\text { Realisasi Belanja Operasi }}{\text { realisasi pendapatan asli daerah }} \times 100
$$

Dengan mengetahui hasil perbandingan antara realisasi belanja dan anggaran belanja daerah dengan menggunakan ukuran efisiensi tersebut, maka penilaian kinerja keuangan dapat ditentukan.Kriteria efisiensi:

1) Jika diperoleh nilai kurang dari $100 \%(\mathrm{x}<100 \%)$ berarti efisien.

2) Jika diperoleh nilai sama dengan $100 \%(\mathrm{x}=100 \%)$ berarti efisien berimbang.

3) Jika diperoleh nilai lebih dari $100 \%(x>100 \%)$ berarti tidak efisien 
d. Rasio keserasian belanja

Rasio keserasian menggambarkan bagaimana pemerintah daerah memprioritaskan alokasi dananya pada belanja aparatur dan belanja pelayanan publik secara optimal.Dalam penelitian ini digunakan proprosi belanja publik karena belanja publik secara langsung dimaksudkan untuk dapat meningkatkan kesejahteraan hidup masyarakat. Rasio keserasian diukur dengan membandingkan realisasi total belanja operasi dengan total belanja daerah dalam satuan persen. rasio ini dihitung dengan:

$$
\text { Rasio Keserasian Belanja }=\frac{\text { Belanja Operasi }}{\text { Total Belanja Daerah }} \times 100
$$

Dengan mengetahui hasil perbandingan antara realisasi belanja dan anggaran belanja daerah dengan menggunakan ukuran efisiensi tersebut, maka penilaian kinerja keuangan dapat ditentukan sebagai berikut Mahsun (2014:154)

1) Jika diperoleh nilai kurang dari $100 \%(\mathrm{x}<100 \%)$ berarti kurang serasi.

2) Jika diperoleh nilai sama dengan $100 \%(\mathrm{x}=100 \%)$ berarti serasi.

3) Jika diperoleh nilai lebih dari $100 \%(x>100 \%)$ berarti sangat serasi.

e. Rasio belanja pegawai

Belanja pegawai adalah semua pengeluaran negara yang digunakan untuk membiayai kompensasi dalam bentuk uang atau barang yang diberikan kepada pegawai pemerintah pusat, pensiunan, anggota Tentara Nasional Indonesia/Kepolisian Negara Republik Indonesia, dan pejabat negara, baik yang bertugas di dalam negeri maupun di luar negeri, sebagai imbalan atas pekerjaan yang telah dilaksanakan, kecuali pekerjaan yang berkaitan dengan pembentukan modal (UU Nomor 13 Tahun 2005 Tentang Anggaran Pendapatan dan Belanja Negara Tahun Anggaran 2006). Kemudian dalam deskripsi dan analisis APBD (2014) dinyatakan bahwa rasio belanja pegawai terhadap total belanja daerah digunakan untuk mengetahui proporsi belanja pegawai terhadap total belanja daerah. Data belanja peggawai yang digunakan adalah belanja pegawai langsung dan belanja pegawai tidak langsung.Rasio ini menggambarkan rasio belanja pegawai terhadap belanja daerah.Semakin tinggi angka rasionya maka semakin besar proporsi APBD yang dialoksikan untuk belanja pegawai.Begitupula sebaliknya semakin kecil angka rasio belanja pegawai maka semakin kecil proporsi APBD yang dialokasikan untuk belanja pegawai APBD. Rasio belanja pegawai di ukur dengan rumus sebagai berikut:

$$
\text { Rasio Belanja Pegawai }=\frac{\text { Belanja Pegawai }}{\text { Total Belanja Daerah }} \times 100
$$


f. Belanja modal

Belanja modal adalah pengeluaran pemerintah daerah yang manfaatnya lebih dari satu tahun anggaran dan akan menambah aset atau kekayaan daerah dan berakibat menambah belanja yang bersifat rutin. Belanja modal diklasifikasikan dalam dua kelompok, kelompok pertama adalah belanja publik yaitu belanja yang manfaatnya dapat langsung dinikmati masyarakat misalnya: pembangunan jembatan, pembelian mobil ambulan untuk umum dan Iain-lain. Kelompok kedua adalah belanja aparatur yaitu belanja yang manfaatnya tidak dinikmati langsung oleh masyarakat tetapi dapat dirasakan langsung oleh aparatur misalnya: pembangunan gedung dewan, pembelian mobil dinas dan lain-lain. Hampir semua anggaran belanja modal mengandung komitmen adanya pengeluaran dalam jangka yang cukup panjang.

Dalam PP No. 58 Tahun 2005 disebutkan bahwa belanja modal adalah pengeluaran yang dilakukan dalam rangka pembelian/pengadaan aset tetap dan aset lainnya yang mempunyai masa manfaat lebih dari 12 (dua belas) bulan untuk digunakan dalam kegiatan pemerintahan, seperti dalam bentuk tanah, peralatan dan mesin, gedung dan bangunan, jaringan, buku perpustakaan dan hewan. Dalam Permendagri No. 13 Tahun 2006 belanja modal didefinisikan sebagai pengeluaran yang dilakukan dalam rangka pembelian/pengadaan atau pembangunan aset tetap berwujud yang mempunyai nilai manfaat lebih dari 12 (dua belas) bulan untuk digunakan dalam kegiatan pemerintahan, seperti dalam bentuk tanah, peralatan dan mesin, gedung dan bangunan, jalan, irigasi dan jaringan, dan aset tetap lainnya. Alokasi belanja modal dihitung dengan formula sebagai berikut:

$$
\text { Alokasi Belanja modal }=\frac{\text { Belanja Modal }}{\text { Total Belanja }} \times 100
$$

Dengan demikian maka dapat diketahui bahwa kinerja keuangan daerah dapat dianalisis dengan berbagai rasio keuangan daerah. Seperti tingkat kemandirian daerah dengan rasio kemandirian, tingkat efektivitas dapat diukur dengan rasio efektivitas, tingkat efisiensi dapat diukur degan rasio efisiensi, tingkat belanja pegawai dapat diukur dengan rasio belanja pegawai, dan tingkat belanja modal dapat diukur dengan rasio belanja modal.

\section{Anggaran Pendapatan dan Belanja Daerah}

Menurut Undang-undang nomor 17 Tahun 2003 pasal 1 butir 8 tentang Keuangan Negara menyebutkan bahwa Anggaran Pendapatan dan Belanja Daerah, selanjutnya disebut APBD adalah rencana keuangan tahunan pemerintah daerah yang disetujui oleh Dewan Perwakilan Rakyat Daerah. Semua penerimaan yang menjadi hak dan pengeluaran yang menjadi kewajiban daerah dalam tahun anggaran bersangkutan harus dicatat dalam APBD.

Menurut Halim dan Kusufi (2014:75), Anggaran Pendapatan dan Belanja Daerah merupakan rencana keuangan pemerintah daerah yang menggambarkan perkiraan 
pengeluaran untuk membiayai kegiatan dan proyek daerah selama periode satu tahun dan menggambarkan perkiraan dan sumber penerimaan daerah untuk menutupi pengeluaran.

Selanjutnya Halim dan Kusufi (2014:75) menyatakan bahwa Anggaran Pendapatan dan Belanja Daerah dalam pemerintah daerah berguna sebagai rencana perkiraan tinggi biaya pemasukkan dan pengeluaran anggaran dalam kegiatan dan proyek dalam periode anggaran satu tahun. Dimana didalam APBD sebagai anggaran daerah memiliki unsur-unsur sebagai berikut:

a. Rencana, jenis, dan bentuk proyek dalam bentuk angka maupun uraian dalam satu periode.

b. Batas minimal target dan batas maksimal target pendanaan maupun pengeluaran aktivitas.

Lasminingsih (2014:223) Anggaran Pendapatan dan Belanja Daerah (APBD) adalah suatu rencana kerja pemerintah yang dinyatakan secara kuantitatif, biasanya dalam satuan moneter yang mencerminkan sumber-sumber penerimaan daerah dan pengeluaran untuk membiayai kegiatan dan proyek daerah dalam kurun waktu satu tahun anggaran.

Menurut Saragih (2013), Anggaran Pendapatan dan Belanja Daerah (APBD)adalah dasar dari pengelolaan keuangan daerah dalam tahun anggaran tertentu, umumnya satu tahun. Unsur-Unsur APBD adalah sebagai berikut:

a. Rencana kegiatan suatu daerah, beserta uraiannya secara rinci.

b. Adanya sumber penerimaan yang merupakan target minimal untuk menutupibiayabiaya sehubungan dengan aktivitas tersebut, dan adanya biaya-biayayang merupakan batas maksimal pengeluaran-pengeluaran yang akandilaksanakan.

c. Jenis kegiatan dan proyek yang dituangkan dalam bentuk angka.

d. Periode anggaran yang biasanya 1 (satu) tahun.

Menurut Peraturan Menteri Dalam Negeri Nomor 22 Tahun 2011 tentang Pedoman Penyusunan Anggaran Pendapatan dan Belanja Daerah Tahun Anggaran 2012 pasal 1 dalam Dalam Peraturan Menteri ini yang dimaksud dengan:

a. Anggaran Pendapatan dan Belanja Daerahyang selanjutnya disingkat APBD,adalah rencana keuangan tahunan pemerintahan daerah yang yang dibahas dandisetujui bersama oleh pemerintah daerah dan DPRD, dan ditetapkan denganperaturan daerah.

b. Pedoman Penyusunan APBD, adalah pokok-pokok kebijakan yangharusdiperhatikan dan dipedomani oleh pemerinah daerah dalam penyusunan danpenetapan APBD.

c. Pemerintah Daerah adalah Pemerintah Provinsi dan Pemerintah Kabupaten/Kota.

d. Kepala Daerah adalah Gubernur dan Bupati/ Walikota. 
Berdasarkan pendapat di atas maka dapat diketahui bahwa Anggaran Pendapatan dan Belanja Daerah disusun setiap tahunnya oleh daerah dan akan dilaksanakan atau direalisasikan dalam masa satu periode. Penyusunan Anggaran Pendapatan dan Belanja Daerah ini dimaksudkan untuk menjadi pedoman dalam pelaksanaanya.

\section{METODE PENELITIAN}

\section{Metode Analisis Data}

Metode analisis data menggunakan metode kuantitatif. Metode kuantitatif dinamakan metode tradisional, karena metode ini sudah cukup lama digunakan sehingga sudah mentradisi sebagai metode untuk penelitian, menurut Sugiyono (2014:12). Metode ini menganalisis data yang diperoleh yaitu data laporan realisasi anggaran Kabupaten Aceh Timur dari tahun 2010 sampai dengan tahun 2018.

\section{Peralatan Analisis}

Peralatan analisis yang digunakan untuk menganalisis kinerja keuangan daerah berdasarkan rasio-rasio keuangan daerah yaitu rasio kemandirian, tingkat efektifitas dan efesien

\section{HASIL DAN PEMBAHASAN}

\section{Hasil Penelitian}

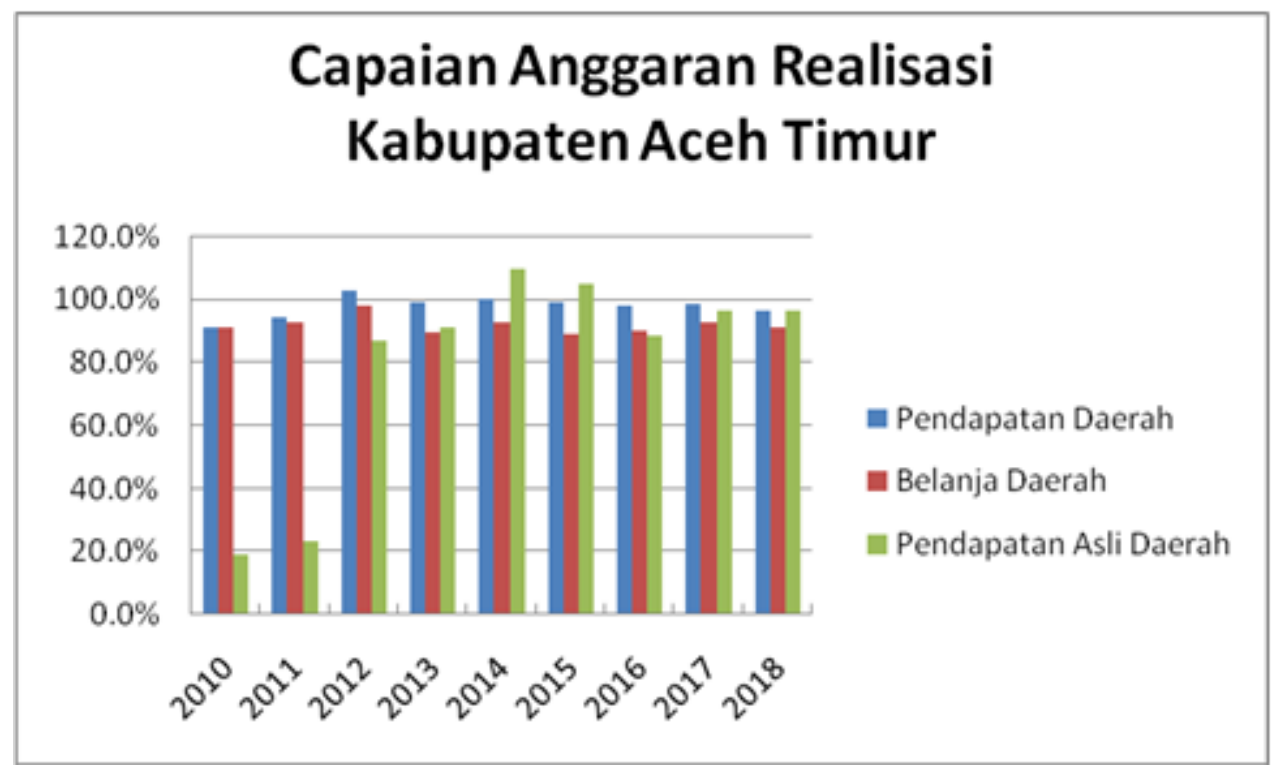

Gambar 4.1. Capaian Anggaran Realisasi Kabupaten Aceh Timur Tahun 2010-2018

Sumber: Laporan Realisasi Anggaran, BPKD Kabupaten Aceh Timur, 2019, (diolah)

Berdasarkan gambar 4.1 menunjukkan grafik capaian anggaran realisasi Kabupaten Aceh Timur bahwa pendapatan daerah berupa dana perimbangan yang bersumber dari transfer umum, transfer khusus, hibah dan otonomi khusus memiliki kinerja kurang baik, ditunjukkan dari hasil rata-rata tingkat capaian anggaran dan realisasi pendapatan daerah dari tahun 2010 sampai dengan 2018 masih dibawah target 
IHTIYATH Jurnal Manajemen Keuangan Syariah

Vol. 5 No. 1, September 2021

yaitu 97\%, hanya saja pada tahun 2012 capaian anggaran dan realisasi melebihi target yaitu $102 \%$.

Begitu juga kinerja pendapatan asli daerah rata-rata tingkat capaian anggaran dan realisasi masih dibawah target yaitu 79\%, angka ini menunjukkan bahwa kemampuan daerah dalam memperoleh pendapatan asli daerah yang bersumber dari pajak, retribusi, zakat dan lain-lain masih kurang optimal, hanya pada tahun 2014 dan 2015 capaian anggaran dan realisasi mencapai target yaitu $109 \%$ dan 105\%. Sedangkan kinerja belanja daerah secara umum menunjukkan kinerja yang baik, dibuktikan dari rata-rata tingkat capaian anggaran realisasi dibawah target yaitu $92 \%$.

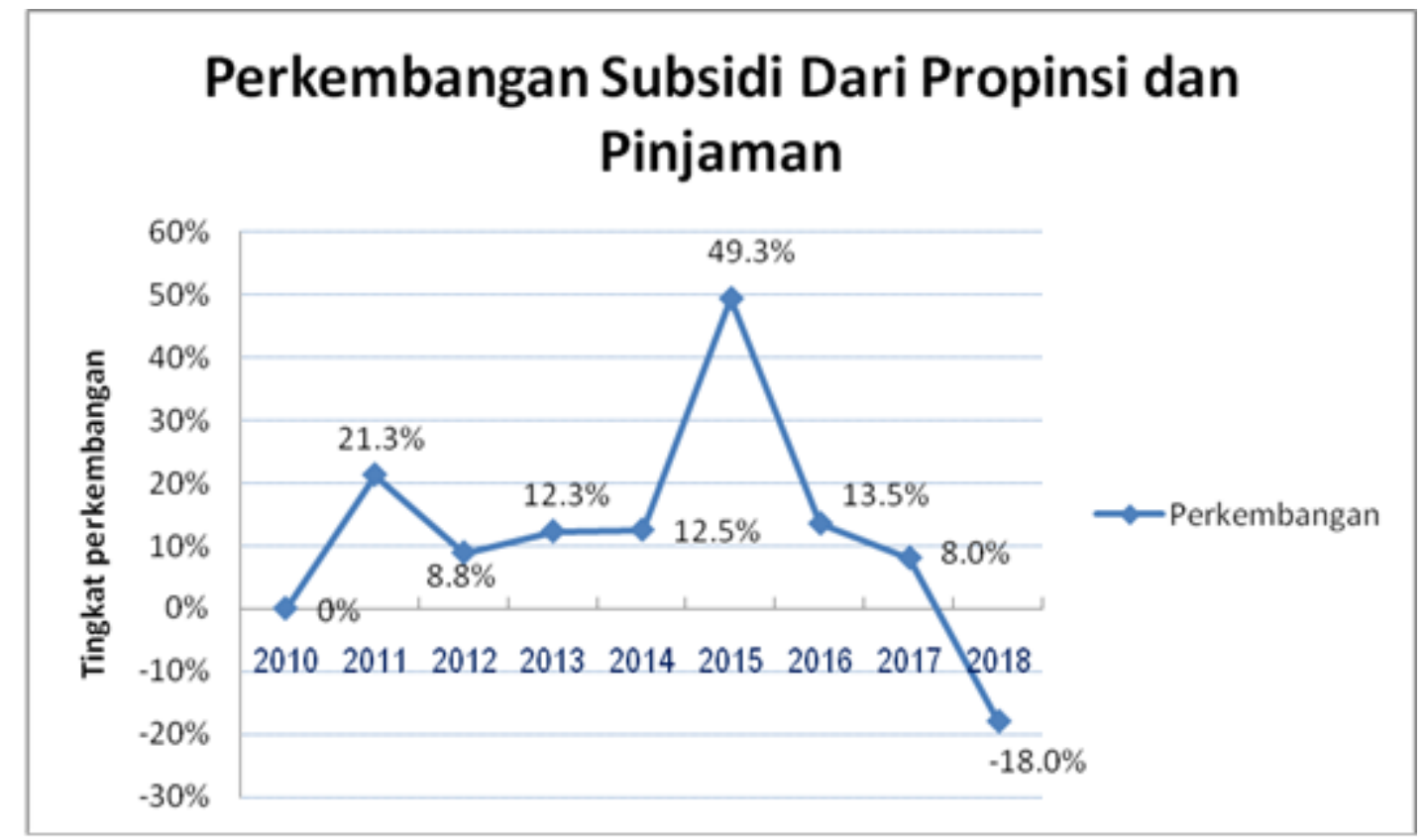

Gambar 4.2. Perkembangan Subsidi dari Propinsi dan Pinjaman Kabupaten Aceh Timur Tahun 2010-2018

Sumber: Laporan Realisasi Anggaran, BPKD Kabupaten Aceh Timur, 2019, (diolah)

Berdasarkan gambar grafik 4.2 menunjukkan bahwa perkembangan subsidi pemerintah pusat berupa Dana Alokasi Umum, Dana Alokasi Khusus, Dana Bagi hasil, Otonomi Khusus, Pinjaman dan hibah setiap tahun mengalami peningkatan yang positif, namun di tahun 2018 jumlah subsidi pemerintah pusat provinsi dan pinjaman daerah mengalami penurunan sampai pada angka negatif yaitu $-18 \%$, hal ini dikarenakan terjadi penurunan jumlah penerimaan di provinsi berupa hibah dan lain-lain pendapatan yang sah. 
Tabel 4.1

Hasil Analisis Kinerja Keuangan berdasarkan Rasio

\begin{tabular}{|c|c|c|c|c|c|c|}
\hline \multirow{2}{*}{ Tahun } & \multicolumn{2}{|c|}{ Kemandirian } & \multicolumn{2}{|c|}{ Efektifitas } & \multicolumn{2}{|c|}{ Efisiensi } \\
\hline & $\begin{array}{c}\text { Tingkat } \\
\%\end{array}$ & Kriteria & $\begin{array}{c}\text { Tingkat } \\
\%\end{array}$ & Kriteria & $\begin{array}{c}\text { Tingkat } \\
\%\end{array}$ & Kriteria \\
\hline 2010 & 1,6 & Rendah sekali & 19,1 & Tidak Efektif & 110,8 & $\begin{array}{c}\text { Tidak } \\
\text { Efisien }\end{array}$ \\
\hline 2011 & 2,0 & Rendah sekali & 23,3 & Tidak Efektif & 97,1 & Efisien \\
\hline 2012 & 2,4 & Rendah sekali & 86,6 & Tidak Efektif & 91,8 & Efisien \\
\hline 2013 & 5,0 & Rendah sekali & 90,9 & Tidak Efektif & 93,9 & Efisien \\
\hline 2014 & 9,0 & Rendah sekali & 109,2 & Efektif & 98,7 & Efisien \\
\hline 2015 & 6,9 & Rendah sekali & 104,9 & Efektif & 84,1 & Efisien \\
\hline 2016 & 5,8 & Rendah sekali & 88,1 & Tidak Efektif & 79,8 & Efisien \\
\hline 2017 & 9,0 & Rendah sekali & 96,5 & Tidak Efektif & 76,8 & Efisien \\
\hline 2018 & 11,8 & Rendah sekali & 96,0 & Tidak Efektif & 99,3 & Efisien \\
\hline $\begin{array}{c}\text { Rata-rata } \\
\text { rasio }\end{array}$ & 5,9 & Rendah sekali & 79,4 & Tidak Efektif & 92,5 & Efisien \\
\hline
\end{tabular}

Sumber: Laporan Realisasi Anggaran, BPKD Kabupaten Aceh Timur, 2019, (diolah)

Tabel 4.1 menunjukkan hasil perhitungan dari analisis kinerja keuangan dengan menggunakan rasio, bahwa berdasarkan hasil perhitungan Kemandirian, pada tahun 2010, 2011, 2012, 2013, 2014, 2015, 2016, 2017 dan 2018 sebesar 1,6\%, 2\%, 2,4\%, $5 \%, 9 \%, 6,9 \%, 5,8 \%, 9 \%$ dan $11,8 \%$ dengan rata-rata rasio $5,9 \%$ dikategorikan tingkat KEMANDIRIAN RENDAH SEKALI, karena besarnya angka yang diperoleh di bawah dari standar kategori rendah yaitu 0-25\%. Dan berdasarkan hasil perhitungan Efektifitas, pada tahun 2010, 2011, 2012, 2013, 2014, 2016, 2017 dan 2018 sebesar 19,1\%, 23,3\%, $86,6 \%, 90,9 \%, 109,2 \%, 104,9 \%, 88,1 \%, 96,5 \%$ dan $96 \%$ dengan rata-rata rasio $79,4 \%$ dikategorikan TIDAK EFEKTIF, karena besarnya angka yang diperoleh di bawah dari standar kategori efektif yaitu < 100\%. Sedangkan berdasarkan hasil perhitungan Efisiensi, pada tahun 2010, 2011, 2012, 2013, 2014, 2015, 2016, 2017 dan 2018 sebesar $110,8 \%, 97,1 \%, 91,8 \%, 93,9 \%, 98,7 \%, 84,1 \%, 79,8 \%, 76,8 \%$, dan $99,3 \%$ dengan ratarata rasio $92,5 \%$ dikategorikan EFISIEN, karena besarnya angka yang diperoleh sesuai stadar kategori efisien yaitu $<100 \%$. 


\section{Pembahasan}

Kinerja keuangan Pemerintah Kabupaten Aceh Timur dalam pengelolaan anggaran pendapatan dan belanja daerah berdasarkan rasio keuangan dapat dijelaskan sebagai berikut:

a. Pengukuran kinerja keuangan berdasarkan rasio kemandirian tergolong tingkat kemandirian yang sangat rendah, dibuktikan dari besarnya angka yang dihasilkan pada tingkat rasio dari tahun 2010-2018, dengan rata-rata angka rasio dibawah 25\% sesuai dengan standar kemandirian. Hal ini menunjukkan bahwa Kabupaten Aceh Timur belum mandiri dan masih sangat membutuhkan bantuan dari pemerintah pusat melalui transfer pemerintah pusat yaitu dana perimbangan (Dana Alokasi Umum, Dana Alokasi Khusus, Dana Bagi Hasil maupun Dana Otonomi Khusus) dan provinsi serta pinjaman untuk operasional Kabupaten Aceh Timur.

b. Pengukuran kinerja keuangan berdasarkan rasio efektivitas tergolong tidak efektif, dibuktikan dari besarnya angka yang dihasilkan pada tingkat rasio dari tahun 2010 sampai dengan 2018 dengan rata-rata rasio efektivitas masih dibawah 100\% sesuai standard efektivitas, artinya kemampuan pemerintah Kabupaten Aceh Timur dalam mengumpulkan Pendapatan Asli Daerah belum optimal, hal ini ditunjukkan dari perbandingan besarnya anggaran dan realisasi Pendapatan Asli Daerah yaitu anggaran Pendapatan Asli Daerah masih lebih besar dibandingkan realisasi Pendapatan Asli Daerah.

Pengukuran kinerja keuangan berdasarkan rasio efisiensi masuk kategori efisien, dibuktikan dari besarnya angka yang dihasilkan pada tingkat rasio dari tahun 2010-2018 dengan rata-rata rasio dibawah $100 \%$ sesuai standard efisiensi, artinya Pemerintah Kabupaten Aceh Timur mampu menekan angka realisasi pembelanjaan dibawah anggaran, dengan kata lain pemerintah mampu menerima pendapatan yang lebih besar dibandingkan dengan biaya yang dikeluarkan.

\section{KESIMPULAN}

Berdasarkan hasil penelitian dan pembahasan dalam penelitian ini, maka penulis mengemukakan kesimpulan penelitian ini sebagai berikut:

a. Pendapatan Asli Daerah di Kabupaten Aceh Timur untuk anggaran masih lebih besar bila dibandingkan dengan realisasinya. Kemudian untuk subsidi pemerintah pusat, provinsi dan pinjaman mengalami perkembangan setiap tahun, hal ini dikarenakan kebutuhan daerah untuk pembangunan. Demikian halnya untuk belanja daerah setiap tahunnya terus meningkat sesuai dengan kebutuhan pembangunan daerah.

b. Kinerja keuangan Kabupaten Aceh Timur dari tahun 2010-2018 kriteria belum mandiri dari sisi ketergantungan pendapatan daerah yang bersumber dari dana perimbangan, terlihat dari rendahnya angka rasio dibawah $25 \%$. Belum efektif dalam perolehan pendapatan asli daerah karena masih tinggi anggaran dibandingkan realisasi dari pendapatan asli daerah, terlihat dari rendahnya angka rasio dibawah 
$100 \%$. Sudah efisien dalam pembelanjaan daerah karena angka pada anggaran lebih tinggi dibanding realisasi, terlihat dari rendahnya angka rasio dibawah $100 \%$.

\section{DAFTAR PUSTAKA}

Halim, Abdul. (2012), Akuntansi Keuangan Daerah, Penerbit Salemba Empat, Jakarta.

Halim, Abdul, dan Kusufi. (2014), Manajemen Keuangan Daerah, Penerbit Salemba Empat, Jakarta.

Kementrian Dalam Negeri. (2011), Peraturan Dalam Negeri Nomor 21 Tahun 2011, tentang Pedoman Pengelolaan Keuangan Daerah, Jakarta

Lasminingsih. (2014), Analisis Kinerja Keuangan Pemerintah, Jurnal EMBA, Vol 7. No 2. Hal 23-33.

Mardiasmo. (2012), Akuntansi Sektor Publik, Penerbit BPFE Yogyakarta.

Mahmudi, (2019), Analisis Laporan Keuangan Pemerintah Daerah, Penerbit UPP STIM YKPN, Yogyakarta.

Mashun, Mohammad. (2014). Pengukuran Kinerja Sektor Publik.Penerbit BPFE, Yogyakarta.

Nurulafifah, 2012, Analisis Kinerja Keuangan Anggaran Pendapatan dan Belanja Daerah (APBD) Kabupaten Sleman tahun 2006-2010, Skripsi, Universitas Negeri Yogyakarta

Peraturan Menteri Dalam Negeri Nomor 13, Tahun 2006 tentang Pedoman Pengelolaan Keuangan Daerah. 2006. Depdagri RI.

Peraturan Pemerintah Nomor 24 tahun 2005.tentang Standar Akuntansi Pemerintahan.

Peraturan Pemerintah Nomor 59 Tahun 2005 tentang Pengelolaan Keuangan Daerah.

Peraturan Pemerintah Nomor 71 tahun 2010 tentang Standar Akuntansi Pemerintahan. Jakarta.

Peraturan Menteri Dalam Negeri Nomor 22 Tahun 2011 tentang Pedoman Penyusunan Anggaran Pendapatan dan Belanja Daerah. Jakarta.

Saragih.P. (2013), Pedoman Pengelolaan Keuangan Daerah. Penerbit Fokus Media, Jakarta.

Sugiyono, (2014), Metode Penelitian, Penerbit Alfabeta, Bandung.

Undang-undang Nomor 13 tahun 2005 tentang anggaran pendapatan dan belanja Negara tahun anggaran 2006. Jakarta

Undang-undang Nomor 32 tahun 2004 tentang Pemerintahan Daerah. Jakarta.

Utama, Suyana.(2012). Pengaruh Kinerja Keuangan Daerah terhadap Kesejahteraan Masyarakat Kabupaten/Kota di Provinsi Bali Tahun 2001-2006.

Zulkarnain.M. Astuti. Y dan Wiriani.E. (2019).Pengaruh Rasio Keuangan Daerah terhadap Pertumbuhan Ekonomi Melalui Belanja Modal di Kota Langsa. Jurnal Samudra Ekonomika. Vol 3.No. 1. Hal 65-73. 